\title{
EHMTI-0147. Medication overuse headache and alexithymia: a controlled study
}

\author{
G Sances $^{1 *}$, F Galli ${ }^{1}$, M Caputi ${ }^{2}$, E Guaschino ${ }^{1}$, MG Cuzzoni ${ }^{1}$, G Nappi ${ }^{1}$, C Tassorelli ${ }^{1}$ \\ From 4th European Headache and Migraine Trust International Congress: EHMTIC 2014 \\ Copenhagen, Denmark. 18-21 September 2014
}

\section{Background}

Alexithymia is a term used to describe a disorder where patients have difficulty in expressing their own feelings in words. The presence of Ax had been related to the occurrence of chronic pain, but poorly studied in headache. Noteworthy, the presence of Alexithymia has been linked to specific correlates at level of posterior cingulated cortex [1].

\section{Aim}

The aim of this study is analyzing the construct of Alexithymia in $\mathrm{MOH}$ patients.

\section{Methods}

A clinical sample of $105 \mathrm{MOH}$ patients $(27 \mathrm{M}, 78 \mathrm{~F}$, mean age $47.49+10.03)$ and 78 control subjects $(28 \mathrm{M}$, $50 \mathrm{~F}$, mean age $41.51+11.03$ ) had been enrolled for the administration of the Toronto Alexithymia Scale.

\section{Results}

Compared to controls, $\mathrm{MOH}$ showed significant values in the total score $(\mathrm{t}(181)=-4.706, \mathrm{p}<001)$, in Factor 1 (Difficulties-in-identifying-feelings) $(\mathrm{t}(181)=-5.296, \mathrm{p}<$ .001 ), Factor 2 (Difficulties-in-describing-feelings) of TAS-20 $(\mathrm{t}(181)=-1.999, \mathrm{p}<.05)$ and a trend for Factor 3 (Outside-oriented-thought) $(\mathrm{t}(181)=-1.799, \mathrm{p}=.099)$, without differences for gender. In $\mathrm{MOH}$ group, a pathological level of Ax is shown by $47 \%$ of patients (vs $15.4 \%$ of controls), a borderline level by $28.1 \%$ (vs $23.6 \%$ ), and no-Ax by $24.9 \%$ (vs $61 \%$ ).

${ }^{1}$ Headache Science Center, C. Mondino National Neurological Institute, Pavia, Italy

Full list of author information is available at the end of the article

\section{Conclusion}

Alexithymia seems an important psychological factor involved in $\mathrm{MOH}$, even if it is not clear which is the link with headache, but pathophysiological and therapeutic meanings should be considered in further studies.

No conflict of interest .

\section{Authors' details}

${ }^{1}$ Headache Science Center, C. Mondino National Neurological Institute, Pavia, Italy. ${ }^{2}$ Psychology, Vita-Salute San Raffaele University, Milan, Italy.

Published: 18 September 2014

\section{Reference}

1. Mantani T, et al: Reduced Activation of Posterior Cingulate Cortex During Imagery in Subjects with High Degrees of Alexithymia: A Functional Magnetic Resonance Imaging Study. Biol Psychiatry 2005, 57:982-990.

\section{doi:10.1186/1129-2377-15-S1-D51}

Cite this article as: Sances et al.: EHMTI-0147. Medication overuse headache and alexithymia: a controlled study. The Journal of Headache and Pain 2014 15(Suppl 1):D51.

\section{SpringerOpen $^{\circ}$}

C 2014 Sances et al; licensee Springer. This is an Open Access article distributed under the terms of the Creative Commons Attribution License (http://creativecommons.org/licenses/by/2.0), which permits unrestricted use, distribution, and reproduction in any medium, provided the original work is properly cited.
Submit your manuscript to a SpringerOpen ${ }^{\circ}$ journal and benefit from:

- Convenient online submission

- Rigorous peer review

- Immediate publication on acceptance

- Open access: articles freely available online

- High visibility within the field

- Retaining the copyright to your article 